\title{
Comparison to Toxic Effects of Copper Oxide Nanoparticles and Copper Sulphate on Some Serum Parameters and Enzyme Activities of Oreochromis niloticus
}

\author{
Mustafa TUNÇSOY* Cahit ERDEM \\ Çukurova University, Faculty of Science and Letters, Biology Department, Adana/Turkey.
}

How to cite: Tunçsoy, M. \& Erdem, C. (2021). Comparison to Toxic Effects of Copper Oxide Nanoparticles and Copper Sulphate on Some Serum Parameters and Enzyme Activities of Oreochromis niloticus. J. Anatolian Env. and Anim. Sciences, 6(4), 514-521.

Atıf yapmak için: Tunçsoy, M. \& Erdem, C. (2021). Bakır oksit nanopartikülleri ve Bakır sülfatın Oreochromis niloticus 'da Serum Parametreleri ve Serum Enzim Aktiviteleri Üzerine Toksik Etkilerinin Karşılaştırılması. Anadolu Çev. ve Hay. Dergisi, 6(4), 514-521.

: https://orcid.org/0000-0001-7306-0539 iD: https://orcid.org/0000-0002-8093-553X
Abstract: Today, human effects due to industrial development and population increase caused water ecosystems to be polluted by various pollutant such as heavy metals. Serum biochemical parameters are widely used in blood analysis and these parameters are suitable indicators for monitoring physiological changes in fish. Hence, the aim of present study to the effects of waterborne copper on serum glucose, total protein, albumin and triglyceride levels and serum cholinesterase (ChE), aspartate aminotransferase (AST), alanine aminotransferase (ALT), alkalane phosphatase (ALP) and lactate dehydrogenase (LDH) activities of O. niloticus were determined after exposing the fish to 10,50 and $100 \mu \mathrm{g} / \mathrm{L}$ copper applied as $\mathrm{CuO}$ nanoparticles (CuO NPs) and $\mathrm{CuSO}_{4}$ over 1,7 and 15 days.

No mortality was observed during the experiments. Serum glucose and albumin levels increased while serum total protein, cholesterol and triglyceride levels decreased compared to control at the end of the 15th day. There was also a decrease in serum ChE activity whereas serum AST, ALT, ALP and LDH activities increased. Overall, $\mathrm{CuSO}_{4}$ and $\mathrm{CuO}$ NPs had similar effects in serum parameters of $O$. niloticus.

\section{*Corresponding author's:}

Mustafa TUNÇSOY

Cukurova University, Faculty of Science and

Letters, Biology Department, Adana/Turkey.

$凶$ : mustafa_tuncsoy@hotmail.com

Keywords: $O$. niloticus, Copper oxide nanoparticles, Copper sulphate, Serum parameters

\section{Bakır oksit nanopartikülleri ve Bakır sülfatın Oreochromis niloticus'da Serum Parametreleri ve Serum Enzim Aktiviteleri Üzerine Toksik Etkilerinin Karşılaştırılması}

*Sorumlu yazar:

Mustafa TUNÇSOY

Çukurova Üniversitesi, Fen-Edebiyat

Fakültesi, Biyoloji Bölümü, Adana/Türkiye

凶: mustafa_tuncsoy@hotmail.com

\begin{abstract}
Öz: Günümüzde endüstriyel gelișmeler ve nüfus artıșına bağlı insan etkileri su ekosistemlerinin ağır metaller gibi çeşitli kirleticiler tarafından kirletilmesine neden olmuştur. Serum biyokimyasal parametreleri kan analizinde yaygın olarak kullanılmaktadır ve bu parametreler balıklarda fizyolojik değişikliklerin izlenmesi için uygun belirteçlerdir. Bu çalışmada 10, 50 ve $100 \mu \mathrm{g} / \mathrm{L} \mathrm{CuO}$ nanopartikülleri (CuO NP) ve bakır sülfatın $\left(\mathrm{CuSO}_{4}\right)$ 1, 7 ve 15 günlük sürelerle etkisinde $O$. niloticus' da serum glikoz, total protein, albumin, kolesterol ve trigliserit düzeyleri ile serum Kolinesteraz (ChE), Aspartat aminotransferaz (AST), Alanin aminotransferaz (ALT), Alkalen fosfataz (ALP) ve Laktat dehidrojenaz (LDH) enzim aktivitelerinin belirlenmesi amaçlanmıştır.

Deney süresince tüm derişimlerde herhangi bir mortalite gözlenmemiştir. 15 günlük deney süresi sonunda her iki ugulamada da serum glikoz ve albümin düzeyleri artış gösterirken, serum total protein, kolesterol ve trigliserit düzeylerinde azalış gösterdiği belirlenmiştir. Serum enzim aktivitelerinde ise ChE aktivitesi azalma gösterirken, serum AST, ALT, ALP ve LDH aktiviteleri deney süresi sonunda artış göstermiştir. Sonuç olarak $O$. niloticus serum parametreleri üzerine toksik etkileri karşılaştırıldığında her iki uygulamanın da benzer etkiler gösterdiği belirlenmiştir.
\end{abstract}

Anahtar kelimeler: O. niloticus, Bakır oksit nanopartikülleri, Bakır sülfat, Serum parametreleri.

\section{INTRODUCTION}

Small amounts of heavy metals enter aquatic environments by volcanic activities, floods and erosion. These natural gradual entries do not impose any danger to aquatic biota due to various adaptive mechanisms. Severe increases observed in the amount of heavy metals entering these habitats mainly due to anthropogenic activities, however, result in serious environmental and human health problems (De et al., 2010; Jorgensen, 2010). In recent years, 
the rapid development in industry and agriculture and population growth in the industry cause the aquatic environment to be polluted by various water pollutants especially heavy metals (Wang et al., 2013; Ji et al., 2015).

In recent years, the production of nanomaterials has been increasing in industrial areas, in addition to this, there has been an increase in the widespread use of various uses, especially in the fields of biomedical and biotechnology (Gomes et al., 2013). Considering their chemical composition, the most important of the nanoparticles are carbon based - and metal oxides (Klaine et al., 2008; Bhatt \& Tripathi, 2011). As a result of the increasing use of metal oxide nanoparticles, these particles reach aquatic environments via after disposal of NP-containing products and the effluent of wastewater treatment plants and application of biosolids to soil, or leachates from landfills (Tolaymat et al., 2017; Bundschuh et al., 2018). In recent years, toxicological research has focused on metal oxide nanoparticles from these type of nanoparticles. (Ringwood et al., 2010; Buffet et al., 2011).

Hematological and biochemical parameters are widely used in blood analysis and these parameters are suitable indicators for monitoring physiological changes in fish. Serum biochemical analysis provides information about internal organs, electrolytes, proteins, nutritional and metabolic parameters (Newman et al., 1997).

$O$. niloticus, which is used as a material in the research, is a tropical fish, and it is widely cultivated in culture conditions since it is consumed as a protein source. The reason why their cultivation in culture conditions is widespread is that they are highly resistant to temperature and salinity changes in tropics and subtropics, have a short food chain, adapt in a short time to intensive stocking, and are suitable for maintenance and nutrition under culture conditions. (Tunçsoy \& Erdem, 2018). It is also important to know whether different forms of metal have different effects on biological functions of fish. Hence the present study was undertaken to compare the toxic effects of $\mathrm{CuO}$ nanoparticles and $\mathrm{CuSO}_{4}$ on some serum parameters and serum enzymes of $O$. niloticus

\section{MATERIAL AND METHOD}

Commercially available $\mathrm{CuO}$ nanopowder (SigmaAldrich; particle size <50nm) and $\mathrm{CuSO}_{4}$ (Sigma Aldrich; $\mathrm{CuSO}_{4}: 5 \mathrm{H}_{2} \mathrm{O}$ ) were used in the experiment. Solutions were replaced daily by serial dilutions of freshly prepared 100 ppm stock solutions of the metal. Before each renewal $\mathrm{CuO}$ solution was sonicated for $30 \mathrm{~min}$ (Ultrasonic bath $230 \mathrm{~V}$, $200 \mathrm{~W}, 45 \mathrm{kHz}$ frequency) before each renewal to break down the size of aggregates. Results of characterization of $\mathrm{CuO}$ nanoparticles are given Tunçsoy and Erdem, (2018).
O. niloticus was obtained from the rearing pools of Fisheries Faculty, Çukurova University, Adana, Turkey. The mean length and weight of fish were $20.50 \pm 1.50 \mathrm{~cm}$ and $170.95 \pm 5.21 \mathrm{~g}$ respectively. Fish were adapted to laboratory conditions for one month in glass aquaria $40 \times 120 \times 40 \mathrm{~cm}$ in height. Experiments were run in triplicate being one fish in each replicate, hence nine fish were placed into each aquarium totaling to 63 fish $(n=63)$. The same sized seven aquaria were used in the experiments. The first six aquarium was filled with $120 \mathrm{~L}$ of $10,50,100 \mu \mathrm{g} \mathrm{Cu} / \mathrm{L}$ as a $\mathrm{Cu}$ NPs and $10,50,100 \mu \mathrm{g} \mathrm{Cu} / \mathrm{L}$ as a $\mathrm{CuSO}_{4}$ solution whereas the seventh one was filled with the same amount of copper free tap water and used as control. Some physical and chemical properties of experimental water are given Tunçsoy and Erdem, (2018).

Fish were fed once a day with readymade fish feed (Pinar, Pellet No: 2) at amounts of $2 \%$ of total biomass and $12 \mathrm{~h} / 12 \mathrm{~h}$ light/dark illumination regime was adopted. Three fish were removed from each aquarium at the end of exposure period and were anesthetized with MS222. They were then washed with tap water and dried with Whatman filter papers. Blood samples to be used for determining sera parameters were obtained by cutting caudal peduncle vertically. They were transferred to anticoagulant free centrifuge tubes and centrifuged at $4000 \mathrm{rpm}$ for 10 minutes (Nuve NF400). Sera samples were then transferred to sera tubes and analyzed using a Beckman Coulter LH 750 autoanalyzer.

\section{RESULTS AND DISCUSSION}

No mortality was observed in experiment. Stress factors such as metal effects cause changes in carbohydrate metabolism by increasing the release of hormones such as cortisol, epinephrine and catecholamine (Vosyliene, 1999). It is stated that the heavy metal effect causes stress in fish, the energy requirement increases under stress conditions and as a result, it stimulates the release of these hormones and causes glycogenesis and mobilization of muscle and liver glycogen (Brown, 1993; Tuncsoy et al., 2016). Many studies have shown that serum glucose levels increase in the case of stress caused by metal effects. (Iwama et al., 1999; Cicik \& Engin, 2005; Ramesh, 2007). Determination of serum total protein level is used as an indicator of liver damage and is a parameter related to the nutritional status of fish and is used as a marker of xenobiotic-induced stress. Total protein and cholesterol are markers of nutritional status in the organism (Yang \& Chen, 2003). The main function of triglycerides is to store and supply cellular energy. It also shows the feeding status of fish.

Table 1. Effects of various NPs and $\mathrm{Cu}$ on blood serum parameters in different fish species. 
Tablo 1. Farklı nanopartiküllerin ve bakırın çeşitli balık türlerinde serum parametreleri üzerine etkileri.

\begin{tabular}{|c|c|c|c|}
\hline Species & NPs Type & Effects & Reference \\
\hline \multirow{4}{*}{ C. carpio } & $\begin{array}{l}\mathrm{CuO} \mathrm{NPs} \\
\mathrm{TiO}_{2} \mathrm{NPs}\end{array}$ & $\begin{array}{l}\text { Both metals cause histopathological } \\
\text { anomalies in the gill and liver tissue. }\end{array}$ & Mansouri et al., 2016 \\
\hline & $\mathrm{Cu} \mathrm{NPs}$ & $\begin{array}{l}\text { Serum triglyceride level increased under } \\
\text { the effect of } 25 \mathrm{ppm} \text { Cu NP on the } 3^{\text {rd }} \text { days } \\
\text { of exposure compared to the control. } \\
\text { Serum cholesterol level increased on the } \\
\text { 14th day under the effect of } 0.25 \mathrm{ppm} \mathrm{Cu} \\
\text { NP and on the } 14 \text { th day under the effect of } \\
25 \text { ppm Cu NP compared to the control. }\end{array}$ & $\begin{array}{l}\text { Mazandarini } \\
\text { Hoseini } 2015\end{array}$ \\
\hline & Ti NPs & $\begin{array}{l}\text { Serum glucose level and AST, ALT ve } \\
\text { ALP activities increased, cholesterol and } \\
\text { total protein levels unchanged. }\end{array}$ & $\begin{array}{l}\text { Tunçsoy \& Duran, } \\
2020\end{array}$ \\
\hline & $\mathrm{Cu}$ NPs & Serum AST and ALT activities increased. & Hoseini et al., 2016 \\
\hline $\begin{array}{l}\text { Salmo } \\
\text { trutta }\end{array}$ & $\mathrm{CuSO}_{4}$ & $\begin{array}{l}\text { Serum glucose and cortisol levels } \\
\text { increased }\end{array}$ & $\begin{array}{l}\text { Nemcsok \& Hughes, } \\
1988\end{array}$ \\
\hline C. gariepinu: & Ti NPs & $\begin{array}{l}\text { Serum AST, ALT, ALP, LDH, glucose } \\
\text { and albumin increased while serum } \\
\mathrm{Na}^{+}, \mathrm{K}^{+} \text {and } \mathrm{Cl}^{-} \text {, total protein, cholesterol, } \\
\mathrm{ChE}^{2} \text { and triglyceride decreased. }\end{array}$ & Tunçsoy, 2021 \\
\hline $\begin{array}{l}\text { Rhamdia } \\
\text { quelen }\end{array}$ & $\mathrm{CuSO}_{4}$ & $\begin{array}{l}\text { Serum glucose level increased, while } \\
\text { total protein level decreased. }\end{array}$ & Pretto et al., 2014 \\
\hline \multirow[t]{3}{*}{ O. mykiss } & $\mathrm{CuCl}_{2}$ & Serum cholesterol levels decreased & Heydarnejad et al., 2013 \\
\hline & $\mathrm{CuONPs}$ & $\begin{array}{l}\text { Serum glucose level and serum AST, } \\
\text { ALT and ALP activities increased, while } \\
\text { serum total protein, total lipid, albumin } \\
\text { and globulin levels decreased. }\end{array}$ & $\begin{array}{l}\text { Abdel-Khalek et al., } \\
2015\end{array}$ \\
\hline & $\mathrm{CuSO}_{4}$ & ALP activity increased. & $\begin{array}{l}\text { Palandökenlier } \\
\text { Kargın, } 2019\end{array}$ \\
\hline \multirow[t]{3}{*}{$\begin{array}{l}O \text { O. } \\
\text { niloticus }\end{array}$} & Zn NPs & $\begin{array}{l}\text { Serum triglyceride levels increased, } \\
\text { whereas cholesterol levels decreased. } \\
\text { There was no changed serum glucose and } \\
\text { total protein levels. }\end{array}$ & Chen et al., 2004 \\
\hline & $\mathrm{CuONPs}$ & $\begin{array}{l}\text { Serum AST, ALT and ALP levels dose- } \\
\text { dependent increased. }\end{array}$ & $\begin{array}{l}\begin{array}{l}\text { Abdel-Latif } \\
2021\end{array} \\
201 \text { al., } \\
\end{array}$ \\
\hline & $\mathrm{ZnONPs}$ & $\begin{array}{l}\text { Serum AST, ALT and ALP activities } \\
\text { increased, while serum total protein and } \\
\text { albumin levels decreased compared to } \\
\text { control. }\end{array}$ & $\begin{array}{l}\text { Abdel-Daim et al., } \\
2019\end{array}$ \\
\hline $\begin{array}{l}\text { Salmo } \\
\text { trutta } \\
\text { caspius }\end{array}$ & $\mathrm{CuO}$ NPs & $\begin{array}{l}\text { Although serum AST, ALP and LDH } \\
\text { activities increased after } 96 \text { hours, ALT } \\
\text { activity increased after } 28 \text { days of } \\
\text { exposure. }\end{array}$ & Kaviani et al., 2019 \\
\hline
\end{tabular}

In this study, serum glucose levels increased with increasing $\mathrm{Cu}$ concentrations and periods in O. niloticus exposed to both $\mathrm{CuO}$ nanoparticles and $\mathrm{CuSO}_{4}$ (Fig 1; $\mathrm{P}<0.05)$. The increase in serum glucose can be explained by the increase in glycogenolysis due to the increased energy demand under the influence of metal stress. Copper increased serum albumin levels in $O$. niloticus after 15 days of exposure, both in metal form (Fig 1; $\mathrm{P}<0.05$ ). This may be due to the increased synthesis of metal-binding proteins to provide more binding sites. In O. niloticus, serum total protein levels also decreased after 7 days of exposure to $\mathrm{CuO}$ NPs and after 15 days of exposure to $\mathrm{CuSO}_{4}$ (Fig. $1 ; \mathrm{P}<0.05$ ), which may result from inhibition of serum protein synthesis due to metal-induced liver injury at prolonged exposures. Serum cholesterol and triglyceride levels of $O$. niloticus also decreased 15 days after exposure to $\mathrm{CuO}$ NPs and $\mathrm{CuSO}_{4}$ (Fig 1; $\mathrm{P}<0.05$ ). The reduction of total serum cholesterol under the influence of copper may be partly the result of liver damage, the use of cholesterol in the synthesis of corticosteroid hormones, or gluconeogenesis. The decrease in serum triglyceride was probably due to meeting energy needs from non-glycogen sources via gluconeogenesis.

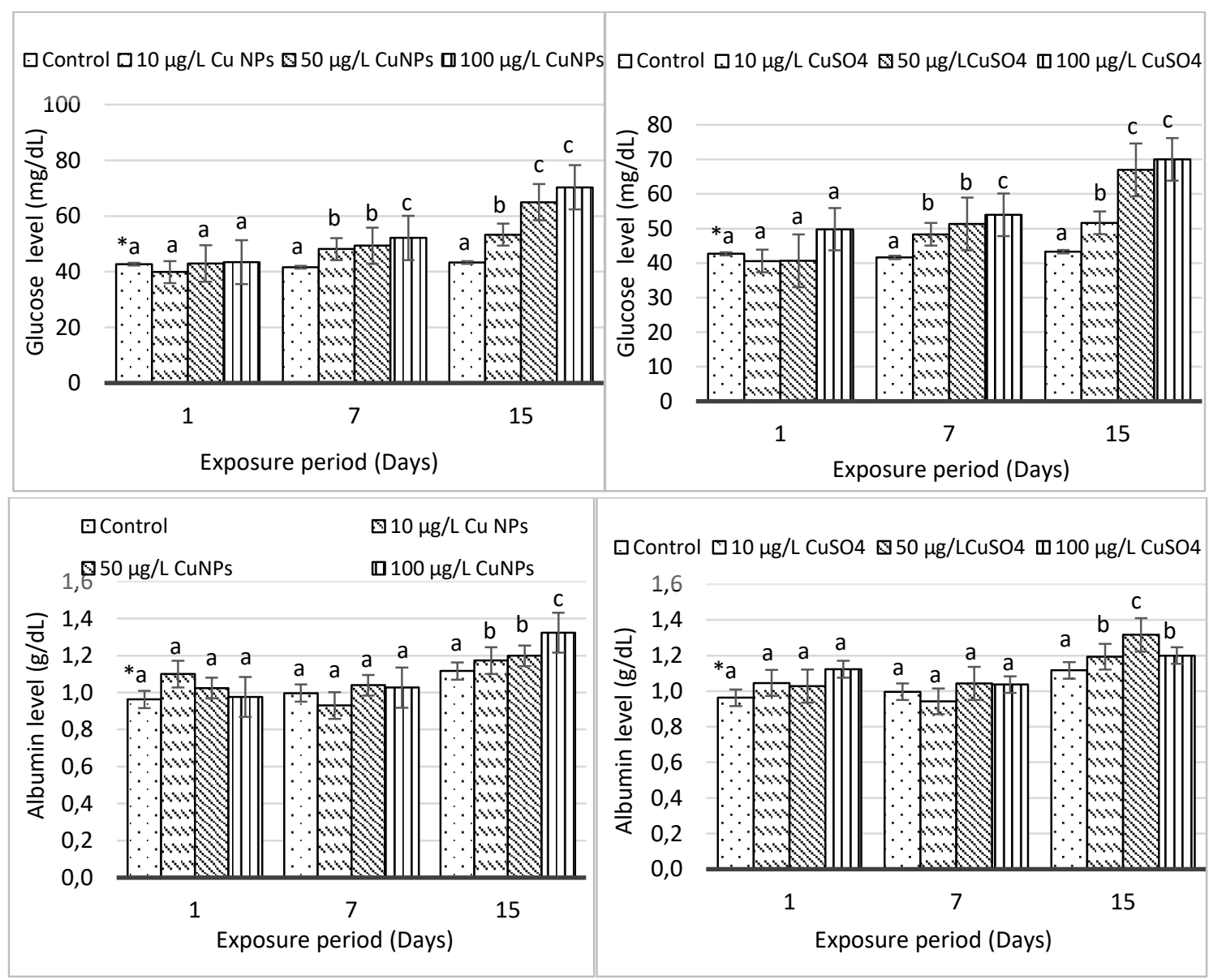




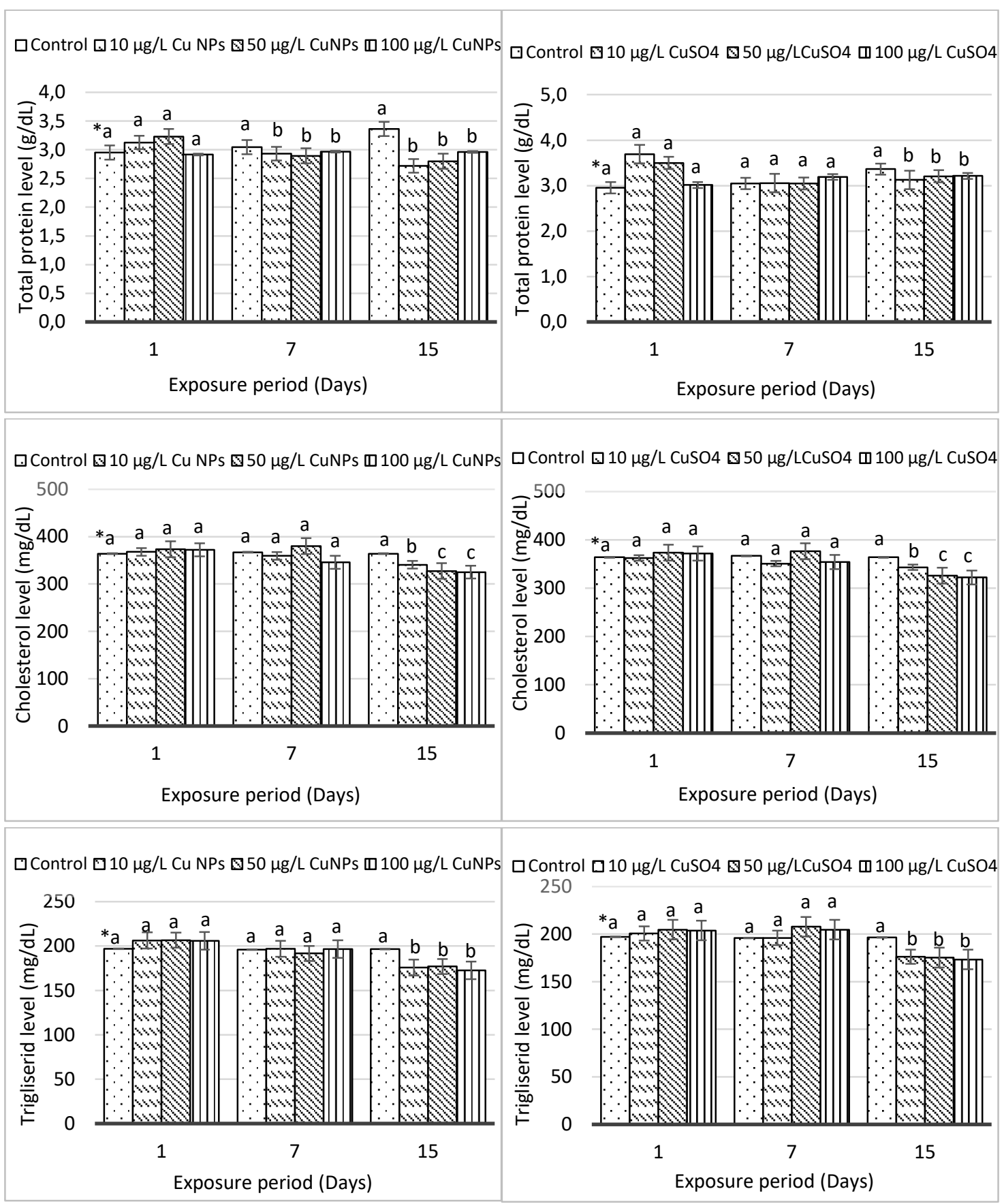

Figure 1. Influence of $\mathrm{Cu} \mathrm{NPs}_{\text {and }} \mathrm{CuSO}_{4}$ on serum parameters of $O$. niloticus.

$*=$ SNK; Letters a, b and c show differences among concentrations. Data shown with different letters are significant at the $\mathrm{P}<0.05$ level.

Serum enzymes such as ChE, AST, ALT, ALP and $\mathrm{LDH}$ are used as sensitive biomarkers to determine the effects of contaminants for aquatic organisms (Levesque et al., 2002; Nel et al., 2009). ChE hydrolyze acetyl choline and other choline-esters. AST and ALT play roles in amino acid metabolism and their increased levels in serum indicate mainly liver, kidney and gill damages (Hoseini et al., 2012). Any damage to liver and kidney tissues increases the level of serum ALP (Karan et al., 1998; Jiraungkoorskul et al., 2003). LDH is an enzyme that catalysis reversible oxidation of lactate to pyruvate and
LDH level increase at any tissue damage (Yousef et al., 2007) .

In the present study, AST, ALT, ALP and LDH activities increased compared to control after 7 and 15 days and $\mathrm{ChE}$ activity decreased after 15 days of exposure to both forms of metal in O. niloticus. These variations in enzyme activities became more pronounced with increasing concentrations of copper and exposure periods (Fig 3; P 00.05). Excess energy used under the effect of copper might be compensated from non-carbohydrate sources and the increase in serum enzyme levels might be attributed to damages in liver and kidney tissues. 


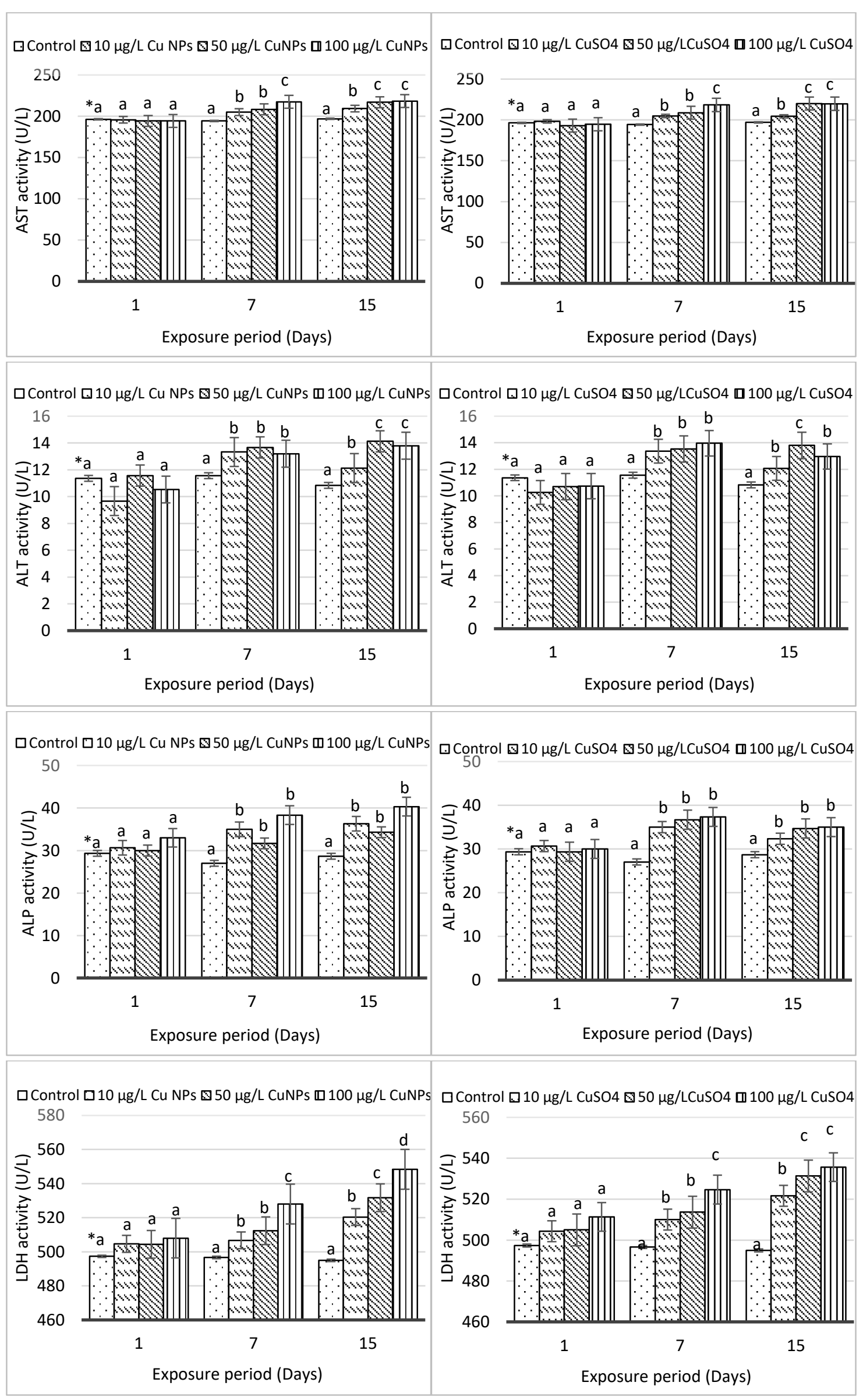




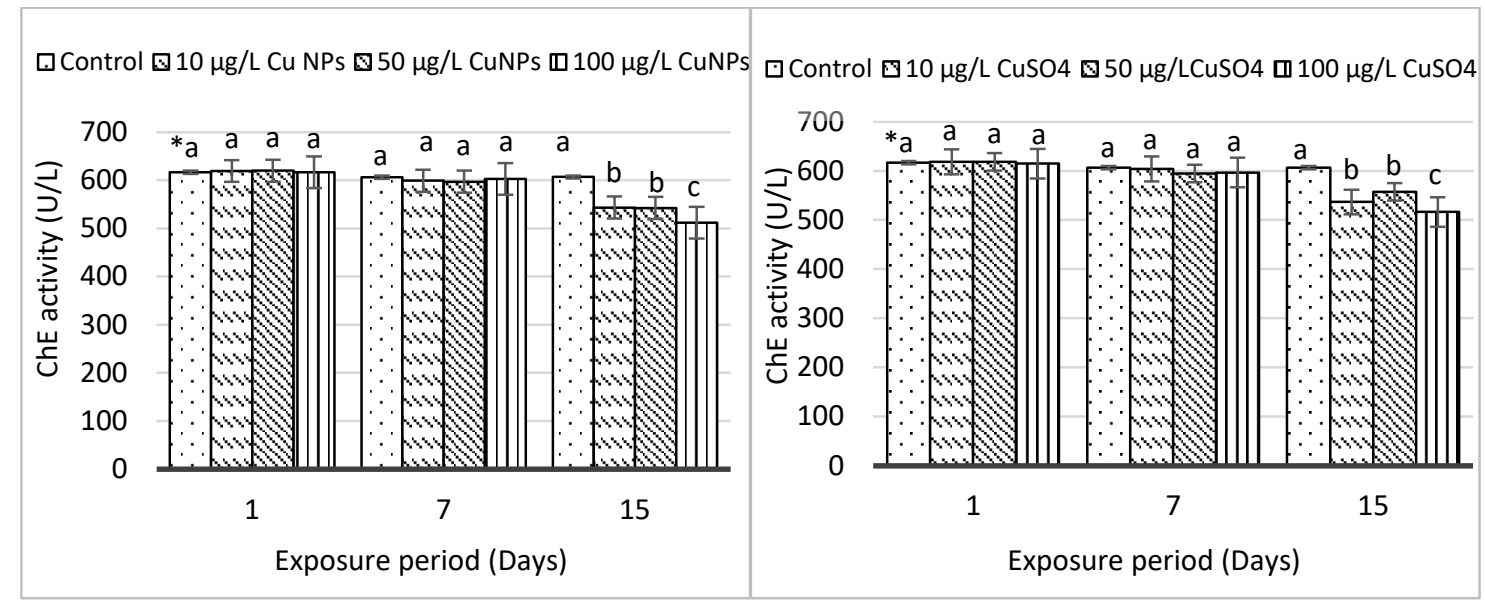

Figure 2. Influence of $\mathrm{Cu} \mathrm{NPs} \mathrm{and} \mathrm{CuSO}_{4}$ on serum enzyme activities in O. niloticus.

* See Fig. 1 for abbreviations

\section{CONCLUSION}

Studying sera biochemical parameters are not only the indicators of physiological stress responses but also can be used as indicators of heavy metal toxicity and these parameters also provide information concerning target organ toxicity. Our results indicate that exposure to the influence of $\mathrm{Cu} \mathrm{NPs}_{\text {s }}$ and $\mathrm{CuSO}_{4}$, serum glucose level increased at 7 and 15 days and serum albumin level increased compared to control at 15 days, while serum total protein, cholesterol and triglyceride levels decreased compared to control after 15 days of exposure. Also, influence of $\mathrm{Cu}$ NPs and $\mathrm{CuSO}_{4}$, serum $\mathrm{ChE}$ activity decreased compared to the control at the end of the 15 days, while serum AST, ALT, ALP and LDH activities increased compared to the control. Overall, $\mathrm{CuSO}_{4}$ and $\mathrm{CuO}$ NPs had similar effects in serum parameters of $O$. niloticus. Periodic determination of physiological and biochemical changes together with the metal concentrations that are consumed as food and accumulated in the tissues of an economically important species as a result of the increasing amounts of heavy metal pollution caused by the increase of technological developments and industrial wastes is of great importance in terms of the structural integrity of the ecosystem, both human health and economic is important. It was concluded that changes in serum parameters studied under the effect of two forms of copper in O. niloticus can be used as copper pollution indicators in freshwater habitats.

\section{ACKNOWLEDGEMENTS}

This study was produced from $\mathrm{PhD}$ thesis and supported by University of Çukurova, Scientific Research Projects Coordination Unit and The Scientific and Technological Research Council of Turkey (TUBITAK). We also thanks to Prof.Dr. Maria João Bebianno, Asst.Prof.Dr. Margarida Ribau Teixeira, Dr. Tânia Gomes and Vânia Sousa.

\section{REFERENCES}

Abdel-Daim, M.M., Eissa, I.A., Abdeen, A., AbdelLatif, H.M., Ismail, M., Dawood, M.A. \& Hassan, A.M. (2019). Lycopene and resveratrol ameliorate zinc oxide nanoparticles-induced oxidative stress in Nile tilapia, Oreochromis niloticus. Environ. Toxicol. Pharmacol, 69, 4450.

Abdel-Latif, H.M.R., Dawood, M.A.O., Mahmoud, S.F., Shukry, M., Noreldin, A.E., Ghetas, H.A. \& Khallaf. M.A. (2021). Copper oxide nanoparticles alter serum biochemical indices, induce histopathological alterations, and modulate transcription of cytokines, hsp 70 , and oxidative stress genes in Oreochromis niloticus. Animals, 11(3), 652.

Abdel-Khalek, A.A., Kadry, M.A.M., Badran, S.R. \& Marie, M.S. (2015). Comparative toxicity of copper oxide bulk and nano particles in Nile Tilapia; Oreochromis niloticus: Biochemical and oxidative stress. J. Basic Appl. Biol., 72, 43-57.

Bhatt, I. \& Tripathi, B.N. (2011). Interaction of engineered nanoparticles with various components of the environment and possible strategies for their risk assessment. Chemosphere, 82(3), 308-317.

Brown, J.A. (1993). Endocrine Responses to Environmental Pollutants. In: Rankin, J.C., Jensen, F.B. (eds.) Fish Ecophysiology. Chapman and Hall, London, UK, s. 276-296.

Buffet, P.E., Tankoua, O.F., Pan, J.F., Berhanu, D., Herrenknecht, C., Poirier, L., Amiard-Triquet, C., Amiard, J.C., Bérard, J.B., Risso, C., Guibbolini, M., Roméo, M., Reip, P., ValsamiJones, E. \& Mouneyrac, C. (2011). Behavioural and biochemical responses of two marine invertebrates Scrobicularia plana and Hediste diversicolor to copper oxide nanoparticles. Chemosphere, 84, 166-174.

Bundschuh, M., Filser, J., Lüderwald, S., McKee, M.S., Metreveli, G., Schaumann, G.E., Schulz, R. \& Wagner, S. (2018). Nanoparticles in the 
environment: where do we come from, where do we go to? Environ. Sci. Eur., 30(1), 6.

Chen, C.Y., Wooster, G.A. \& Bowser, P.R. (2004). Comparative blood chemistry and histopathology of tilapia infected with Vibrio vulnificus or Streptococcus iniae or exposed to carbon tetrachloride, gentamicin or copper sulphate. Aquaculture, 239, 421-443.

Cicik, B. \& Engin, K. (2005). The effects of cadmium on levels of glucose in serum and glycogen reserves in the liver and muscle tissues of Cyprinus carpio (L., 1758). Turk J. Vet. Anim. Sci., 29, 113-117.

De, T.K., De, M., Das, S., Ray, R. \& Ghosh, P.B. (2010). Level of Heavy Metals in Some Edible Marine Fishes of Mangrove Dominated Tropical Estuarine Areas of Hooghly River, North East Coast of Bay of Bengal, India. Bull. Environ. Contam. Toxicol., 85, 385-390.

Gomes, T., Pereira, C.G., Cardoso, C. \& Bebianno, M.J. (2013). Differential Protein Expression in Mussels Mytilus galloprovincialis Exposed to Nano and Ionic Ag. Aquat. Toxicol., 136(137), 7990.

Heydarnejad, M.S., Khosravian-Hemami, M., Nematollahi, A. \& Rahnama, S. (2013). Effects of copper at sublethal concentrations on growth and biochemical parameters in rainbow trout (Oncorhynchus mykiss). Int. Rev. Hydrobiol., 98, 71-79.

Hoseini, S.M., Hosseini, S.A. \& Soudagar, M. (2012). Dietary Tryptophan Changes Serum Stress Markers, Enzyme Activity, and Ions Concentration of Wild Common Carp Cyprinus carpio Exposed to Ambient Copper. Fish Physiol. Biochem., 38(5), 1419-1426.

Hoseini, S.M., Hedayati, A., Taheri Mirghaed, A. \& Ghelichpour, M. (2016). Toxic Effects of Copper Sulfate and Copper Nanoparticles on Minerals, Enzymes, Thyroid Hormones and Protein Fractions of Plasma and Histopathology in Common Carp Cyprinus carpio. Experiment. Toxicol. Pathol., 68(9), 493-503.

Iwama, G.K., Vijayan, M.M., Forsyth, R.B. \& Ackerman, P.A. (1999). Heat Shock Proteins and Physiological Stress in Fish. Am. Zool., 39, 901909.

Jiraungkoorskul, W., Upatham, E.S., Kruatrachue, M., Shaphong, S., Vichasri-Grams, S. \& Pokethitiyook, P. (2003). Biochemical and histopathological effects of glyphosate herbicide on nile tilapia (Oreochromis niloticus). Environ. Toxicol., 18, 260-267.

Ji, C.L., Wang, Q., Wu, H.F., Tan, Q.G. \& Wang, W.X. (2015). A Metabolomic investigation of the effects of metal pollution in oysters Crassostrea hongkongensis. Mar. Pollut. Bull., 90, 21-222

Jorgensen, S.W. (2010). A Derivative of Encyclopedia of Ecology. In: Ecotoxicology. Academic Press, London, pp. 390.

Karan, V., Vitorović, S., Tutundžić, V. \& Poleksić, V. (1998). Functional enzymes activity and gill histology of carp after copper sulfate exposure and recovery. Ecotoxicol. Environ. Safe., 40(1), 49-55.

Kaviani, E., Naeemi, A. \& Salehzadeh, A. (2019). Influence of copper oxide nanoparticle on hematology and plasma bio-chemistry of Caspian trout (Salmo trutta caspius), following acute and chronic exposure. Poll., 5, 225-234.

Klaine, S.J., Alvarez, P.J.J., Batley, G.E., Fernandes, T.F., Handy, R.D., Lyon, D.Y., Mahendra, S., Mclaughlin, M.J. \& Lead, J.R. (2008). Nanomaterials in the environment: Behavior, fate, bioavailability and effects. Environ. Toxicol. Chem., 27(9), 1825-1851.

Levesque, H.M., Moon, T.W., Campbell, P.G.C. \& Hontela, A. (2002). Seasonal variation in carbohydrate and lipid metabolism of yellow perch (Perca flavescens) chronically exposed to metals in the field. Aquat. Toxicol., 60, 257-267.

Mansouri, B., Maleki, A., Davari, B., Johari, S.A., Shahmoradi, B., Mohammadi, E. \& Shahsavari, S. (2016). Histopathological effects following short-term coexposure of Cyprinus carpio to nanoparticles of $\mathrm{TiO}_{2}$ and $\mathrm{CuO}$. Environ. Monit. Assess., 188(575), 5-12.

Mazandarini, M. \& Hoseini, S.M. (2015). Anaemia and plasma lipid profile in common carp (Cyprinus carpio) exposed to ambient copper sulphate and nano-scale copper oxide. Aquac. Res., 1-9.

Nel, A.E., Madler, L., Velegol, D., Xia, T., Hoek, E.M., Somasundaran, P., Klaessig, F., Castranova, V. \& Thompson, M. (2009). Understanding biophysiochemical interactions at the nanobio interface. Nat. Mater., 8, 543-557.

Nemcsok, J. \& Hughes, G.M. (1988) The effect of copper sulphate on some biochemical parameters of rainbow trout. Environ. Poll., 49, 77-85

Newman, S.H., Piatt, J.F. \& White, J. (1997). Hematological and plasma biochemical reference ranges of alaskan seabirds: Their ecological significance and clinical importance. Colon Waterbirds, 20(3), 492-504.

Palandökenlier, E. \& Kargın, F. (2019). The effects of zinc oxide nanoparticles and zinc sulphate on some biochemical parameters in blood tissue of Oreochromis niloticus. Anatolian Env. and Anim. Sciences, 4(3), 447-453.

Pretto, A., Loro, V.L., Silva, V.M.M., Salbego, J., de Menezes, C.C. \& Souza, C.F. (2014). Exposure to sublethal concentrations of copper changes biochemistry parameters in silver catfish, Rhamdia quelen, (Quoy \& Gaimard, 1824). Bull. Environ. Contam. Toxicol., 392-399

Ramesh, M., Senthil Kumaran, S., Kavith, C., Saravanan, M. \& Mustafa, A. (2007). Primary stress responses of common carp, Cyprinus carpio exposed to copper toxicity. Acta Ichthyol. Piscat., 37, 81-85.

Ringwood, A.H., McCarthy, M., Bates, T.C. \& Carroll, D.L. (2010). The effects of silver nanoparticles on 
oyster embryos. Mar. Environ. Res., 69(1), 549551.

Tolaymat, T., El Badawy, A., Genaidy, A., Abdelraheem, W. \& Sequeira, R. (2017). Analysis of metallic and metal oxide nanomaterial environmental emissions. J. Clean. Prod., 143, 401-412.

Tunçsoy, M., Duran, S., Yesilbudak, B., Ay, O., Cicik, B. \& Erdem, C. (2016). Short term effects of zinc on some sera biochemical parameters and on tissue accumulation of Clarias gariepinus. Fresen. Environ. Bull., 25(2), 658-664.

Tunçsoy, M. \& Erdem, C. (2018). Copper accumulation in tissues of Oreochromis niloticus exposed to copper oxide nanoparticles and copper sulphate with their effect on antioxidant enzyme activities in liver. Water Air Soil Poll., 229(269), 1-10.

Tunçsoy, M. \& Duran, S. (2020). Acute toxicity of titanium dioxide nanoparticles on some serum parameters and enzyme activities of Cyprinus carpio. J. Anatolian Env. and Anim. Sciences, 5(4), 704-710.

Tunçsoy, M. (2021). Impacts of titanium dioxide nanoparticles on serum parameters and enzyme activities of Clarias gariepinus. Bull. Environ. Contam. Toxicol., 106(4), 629-636.

Vosyliene, M.Z. (1999). The effect of heavy metals on hematological indices. Acta Zool. Litv. Hydrobiol., 9, 76-82.

Wang, S.L., Xu, X.R., Sun, Y.X., Liu, J.L. \& Li, H.B. (2013). Heavy metal pollution in coastal areas of south china: A review. Mar. Pollut. Bull., 76(1-2), 7-15.

Yang, J.L. \& Chen, H.C. (2003). Effects of gallium on common carp (Cyprinus carpio): acute test, serum biochemistry, and erythrocyte morphology. Chemosphere, 53, 877-882.

Yousef, M.I., Awad, T.I., Elhag, F.A. \& Khaled, F.A. (2007). Study of the protective effect of ascorbic acid against the toxicity of stannous chloride on oxidative damage, antioxidant enzymes and biochemical parameters in rabbits. Toxicology, 235, 194-202. 